\title{
PENENTUAN KONSTANTA PEGAS MENGGUNAKAN APLIKASI PHYPHOX PADA PERISTIWA OSILASI PEGAS
}

\author{
Herliana Aryanti Ewar*, Marselina Erisna Bahagia, Valeria Jeluna, \\ Richardo Barry Astro, Adrianus Nasar
}

Universitas Flores, Jln. Sam Ratulangi Ende Flores e-mail": ariyanti8897@gmail.com

\begin{tabular}{c|c|c}
\hline Diterima 28 Juni 2021 & Disetujui 17 Desember 2021 & Dipublikasikan 31 Desember 2021 \\
\hline \multicolumn{3}{|c}{ https://doi.org/10.33369/jkf.4.3.155-162 } \\
\hline
\end{tabular}

\begin{abstract}
ABSTRAK
Penelitian ini bertujuan untuk menentukan nilai konstanta pegas pada peristiwa osilasi pegas dengan massa benda yang berubah-ubah. Penelitian dilakukan melalui eksperimen menggunakan menu spring pada aplikasi phyphox. Pengumpulan data massa, panjang pegas, pertambahan panjang pegas dilakukan melalui pencatatan manual sedangkan periode dan frekuensi dapat diperoleh melalui tampilan menu spring pada Smartphone. Analisis data menggunakan persamaan regresi linear. Hasil penelitian menunjukan 1) pegas 1 dengan massa $10 \mathrm{~g}$ dan panjang $6 \mathrm{~cm}$ memiliki konstanta sebesar 7,424 N/m $\pm 0,00092,2$ ) pegas 2 dengan massa $50 \mathrm{~g}$ dan panjang $15 \mathrm{~cm}$ memiliki konstanta sebesar $11,084 \mathrm{~N} / \mathrm{m} \pm 0,00078$, dan 3) pegas 1 dengan massa $50 \mathrm{~g}$ dan panjang $\mathrm{cm} \mathrm{cm}$ memiliki konstanta sebesar $24,92 \mathrm{~N} / \mathrm{m} \pm 0,0016$.
\end{abstract}

Kata kunci: konstanta pegas, phyphox, osilasi

\begin{abstract}
This research aims to determine the value of the spring constant in the spring oscillation with different value of load mass. The research was conducted through experiments using the spring menu on the phyphox application. Data collection of mass, spring length, spring length increase is done through manual recording while the period and frequency can be obtained through the spring menu display on the Smartphone. Data analysis used linear regression equation. The results showed 1) spring 1 with a mass of $10 \mathrm{~g}$ and a length of $6 \mathrm{~cm}$ had a constant of $7.424 \mathrm{~N} / \mathrm{m} \pm$ $0.00092,2)$ spring 2 with a mass of $50 \mathrm{~g}$ and a length of $15 \mathrm{~cm}$ had a constant of $11.084 \mathrm{~N} / \mathrm{m} \pm 0.00078$, and 3) spring 1 with a mass of $50 \mathrm{~g}$ and a length of $\mathrm{cm} \mathrm{cm}$ has a constant of $24.92 \mathrm{~N} / \mathrm{m} \pm 0.0016$.
\end{abstract}

Keywords: spring constant, phyphox, oscillation

\section{PENDAHULUAN}

Gerakan sebuah benda secara periodik dan terjadi dalam selang waktu tertentu melalui titik kesetimbangan disebut osilasi (1). Peristiwa osilasi banyak ditemukan dalam kehidupan sehari-hari, misalnya pada pristiwa pegas yang digantung secara vertikal yang diberi beban (2). Beban yang terikat pada ujung pegas dengan massa m diberi simpangan x (Gambar 1) kemudian dilepas maka sistem akan bergerak secara periodik pada titik setimbang yang disebabkan oleh gaya pemulih, gerakan ini disebut gerak harmonik sederhana (3). 


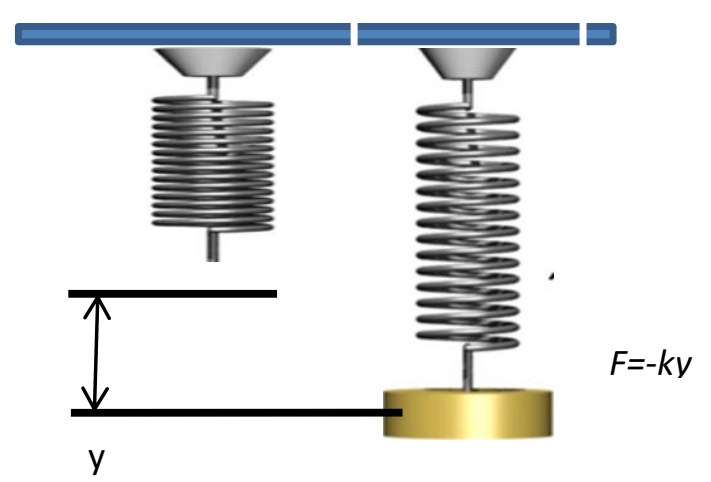

Gambar 1. Pegas sebelum dan sesudah digantung beban

Gambar 1 menunjukkan pegas sebelum digantung beban dan setelah digantung beban. Keadaan ini berlaku Hukum Hooke (4) dengan rumus

$\mathrm{F}=-\mathrm{k} \cdot y$

ketika pegas itu ditarik kemudian dilepaskan maka berlaku Hukum II Newton (4) yaitu:

$\mathrm{F}=\mathrm{m}$ a atau

$F=m \frac{d^{2} y}{d t^{2}}$

Pegas yang dilepas akan mengalami gerak harmonik (4) dengan persamaan:

$y=A \sin (\omega t+\varphi)$

Jika pers. (3) dimasukkan ke pers. (2) maka diperoleh:

$$
F=m \frac{d^{2} y}{d t^{2}}=-\omega^{2} m A \sin (\omega t+\varphi)
$$

Dari pers. (4) dan pers. (1)

$$
-\omega^{2} m A \sin (\omega t+\varphi)=-k A \sin (\omega t+\varphi)
$$

Di mana $\omega=\frac{2 \pi}{T}=2 \pi f$

Sehingga,

$$
T^{2}=\frac{4 \pi^{2}}{k} m
$$

Dimana y adalah Simpangan (m), A adalah Amplitudo, m adalah Massa (Kg), T adalah Periode (s), $\omega$ adalah Kecepatan sudut $(\mathrm{rad} / \mathrm{s})$, f adalah Frekuensi $(\mathrm{Hz}), \mathrm{t}$ adalah Waktu (s), dan Besaran $\frac{4 \pi^{2}}{k}$ merupakan gradien dari pers. (5).

Gerak harmonik yang terjadi pada suatu benda dapat bertujuan untuk memahami peristiwa osilasi pegas dan menentukan nilai konstanta pegas (2). Gaya yang diberikan pada sebuah benda yang menyebabkan benda bertambah panjang disebut konstanta pegas (3).

Pada umumnya percobaan penentuan konstanta pegas masih dilakukan secara manual, penentuan periode dan frekuensi masih menggunakan metode perhitungan manual. Penelitian tentang konstanta pegas telah dilakukan sebelumnya yang dianalisis dengan menggunakan persamaan konsep Hukum Hooke (5).

Penelitian tentang konstanta pegas telah dilakukan dengan berbagai cara yakni pada percobaan yang menggunakan software LabVIEW yang memanfaatkan sensor ultrasonik untuk pemrosesan data, akuisisi data, control dan visualisasi (6). Selain itu dapat juga menggunakan Smartphone untuk medeteksi intensitas cahaya melalui sensor cahaya agar mendapatkan nilai konstanta pegas (7).

Smartphone merupakan alat komunikasi modern yang fleksibel, nyaman dan popular. Smartphone juga banyak menyediakan aplikasi-aplikasi yang membantu eksperimen dalam pembelajaran fisika (7). Smartphone sangat cocok dijadikan sebagai alat eksperimen, karena biasanya dilengkapi dengan sejumlah sensor dan juga sebagai penyimpan dokumen (8). Selain itu, Penggunaan Smartphone menawarkan kemungkinan untuk menerapkan kegiatan seperti laboratorium selama waktu belajar mandiri dan untuk memfokuskan proses pemecahan masalah (9). Smartphone memiliki banyak aplikasi yang dapat membantu guru dalam proses belajar mengajar, 
seperti pengukuran gaya, linear accelerometer, gyroscope, barometer, roller coaster, penggaris, magnetometer, kompas, global positioning system/GPS, stroboscope (beta), inclinometer, light meter, detektor warna, pengukur suara, generator nada, ruang lingkup silau, spektogram penganalisis spektrum (audio), multi-media, generator warna (10). Walaupun eksperimen fisika yang memanfaatkan sensor Smartphone sangat praktis dan hemat biaya, tetapi terdapat beberapa kelemahan seperti telepon tidak dapat diakses selama percobaan dan data biasanya perlu dianalisis selanjutnya dikomputer. Masalah- masalah tersebut dapat diatasi dengan menggunakan aplikasi "phyphox" (7).

Salah satu cara untuk mengatasi masalah tersebut yaitu dengan penggunaan teknologi berbasis aplikasi. Aplikasi yang cocok dengan percobaan penentuan konstanta pegas adalah aplikasi phyphox. Phyphox (physical phone experiments) adalah sebuah aplikasi yang dapat membantu beberapa percobaan dalam praktikum fisika, aplikasi ini dirilis di Google Play Store dan AppleApp Store pada bulan September 2016 (11). Aplikasi Phyphox pertama kali dikembangkan oleh Universitas Aachen dan memanfaatkan Smartphone sebagai sensor dalam pengoperasianya (12). Adapun kelebihan dari aplikasi ini adalah dapat dimiliki tanpa harus dibayar, akan tetapi ada beberapa simulasi yang terdapat dalam phyphox ini tidak dapat disimulasikan apabila smartophone tidak terdapat sensor-sensor simulasi (13). Aplikasi phyphox juga dapat membantu dalam pratikum fisika lainnya seperti dalam percobaan tumbukan tidak lenting, percepatan sentripetal dan pegas (14). Berikut ini adalah tampilan fitur-fitur yang ada pada aplikasi phyphox.

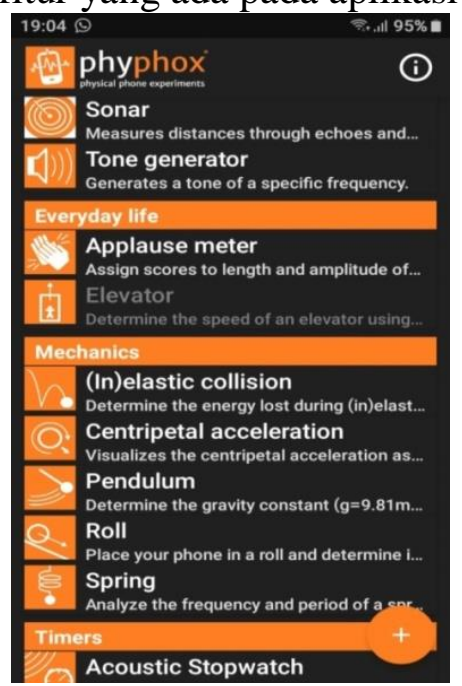

Gambar 2. Tampilan fitur aplikasi phyphox

Menu spring berfungsi untuk menganalisis frekuensi dan periode pada osilasi pegas. Pada menu spring terdapat beberapa fitur seperti results, resonance, autocorrelation dan raw data. Fungsi dari fitur-fitur tersebut adalah sebagai berikut:

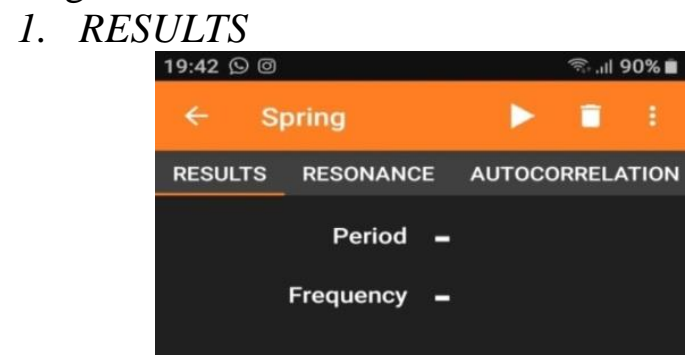

Gambar 3a. Tampilan menu results sebelum percobaan

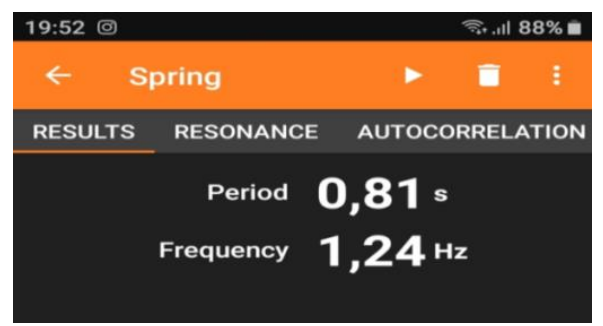

Gambar 3b. Tampilan menu results setelah percobaan

Fitur results berfungsi untuk menampilkan nilai periode dan frekuensi setelah percobaan. 


\section{RESONANCE}

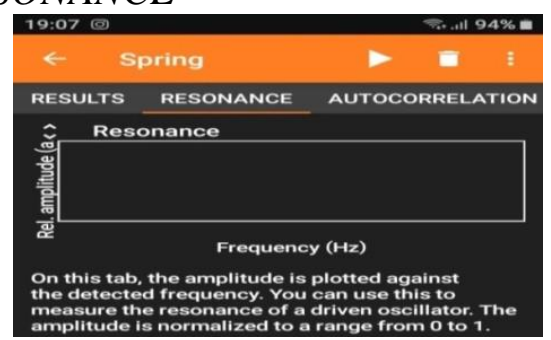

Gambar 4a. Tampilan menu resonance sebelum percobaan.

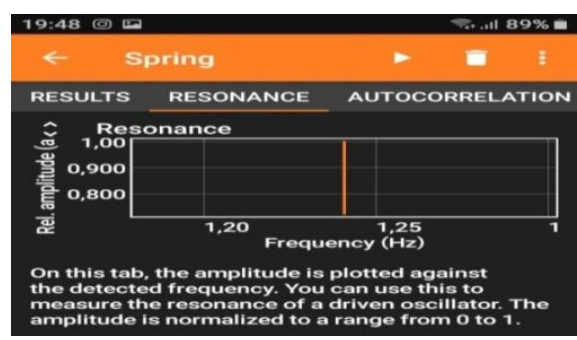

Gambar 4b. Tampilan menu resonance setelah percobaan.

Fitur resonance berfungsi untuk mendeteksi nilai frekuensi alami sistem tempat bekerja.

3. AUTOCORRELATION

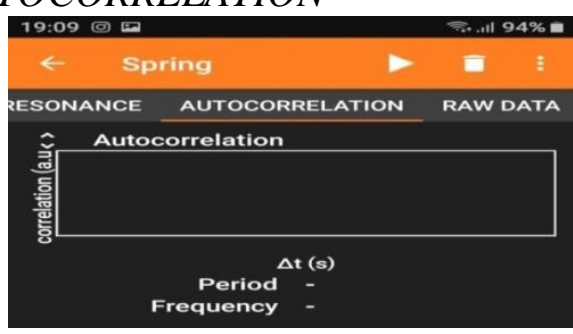

Gambar 5b. Tampilan menu autocorrelation sebelum percobaan.

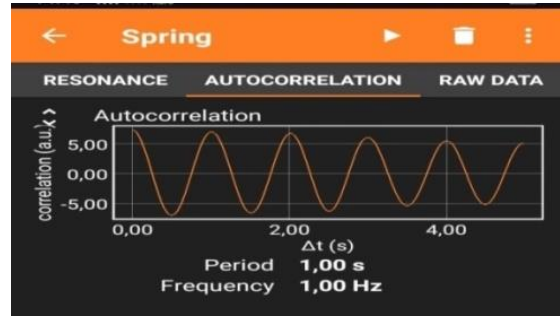

Gambar 5b. Tampilan menu autocorrelation setelah percobaan.

Fitur autocorrelation berfungsi menampilkan data periode dan frekuensi.

\section{RAW DATA}

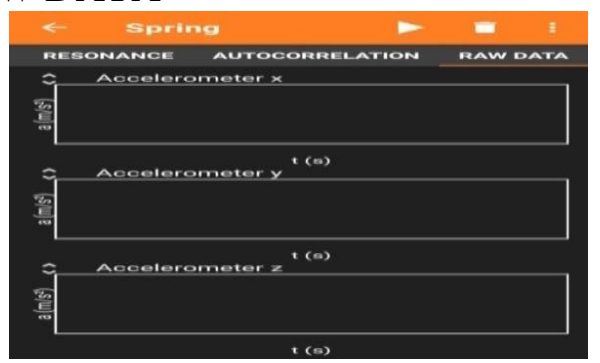

Gambar 6a. Tampilan menu raw data sebelum percobaan.

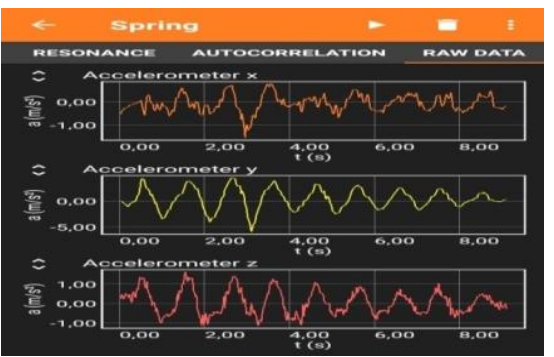

Gambar 6b. Tampilan menu raw data setelah percobaan.

Fitur ini berfungsi untuk menampilkan accelerometer $\mathrm{x}, \mathrm{y}$ dan $\mathrm{z}$.

\section{METODE PENELITIAN}

Penelitian ini merupakan jenis penelitian eksperimen dan dilaksanakan di bengkel Fisika Program studi Pendidikan Fisika universitas Flores menggunakan Statip dan pegas. Penelitian eksperimen meliputi persiapan, penentuan variabel bebas dan variabel terikat, pengumpulan data, analisis dan penarikan kesimpulan (5). Berikut merupakan gambar struktur penelitian eksperimen

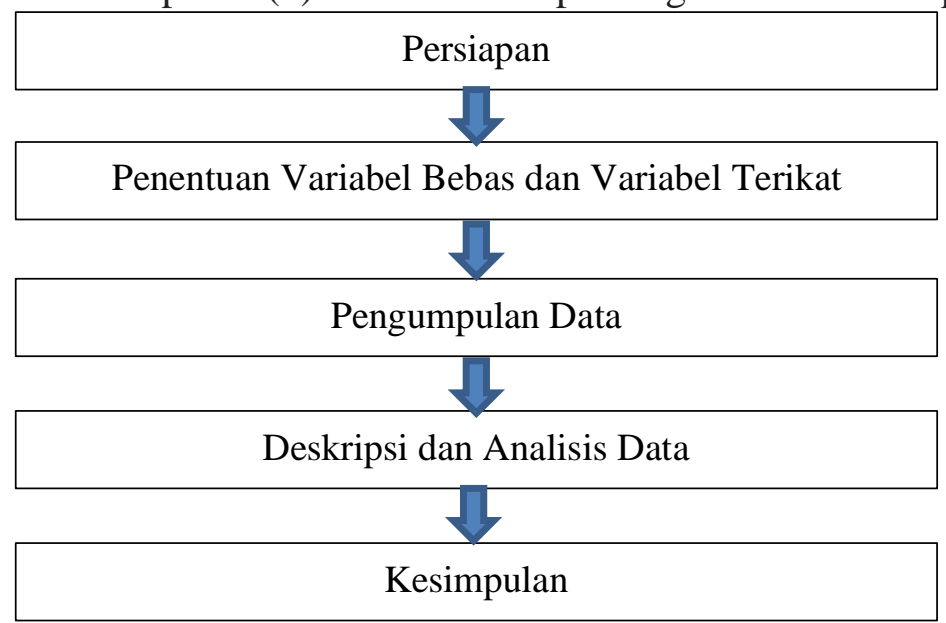

Gambar 7. Bagan struktur penelitan 
Pada tahap pertama mengumpulkan alat dan bahan. Adapun alat dan bahan yang digunakan dalam percobaan ini adalah pegas, statif, neraca, mistar, laptop, Smartphone dan beban dengan massa $50 \mathrm{~g}$ dan $100 \mathrm{~g}$. Tahap kedua adalah menentukan variabel bebas dan variabel terikat. Dalam percobaan ini variabel bebasnya adalah massa benda $(\mathrm{kg})$ yang digantung pada ujung pegas dan variabel terikatnya adalah pertambahan panjang pegas, periode, dan frekuensi setelah digantung beban. Tahap ketiga adalah pengumpulan data yaitu dengan mengatungkan beban pada ujung pegas, mengukur pertambahan panjang pegas jika massanya ditambahkan kemudian pegas diberi simpangan $\pm 5 \mathrm{~cm}$ dan dilepas hingga berosilasi sampai 10 kali. percobaan diulang sampai 10 kali dengan pertambahan massa yang konstan $(50 \mathrm{~g}$ atau $100 \mathrm{~g})$ untuk menentukan nilai periode dan frekuensi. Tahap keempat adalah deskripsi dan analisis data, setelah melakukan percobaan langkah selanjutnya adalah membuat tabel data hasil percobaan pegas 1, 2 dan 3 dan membuat grafik hubungan massa dan periode menggunakan persamaan regresi linear. Persamaan regresi linear yang dihasilkan dapat digunakan untuk menentukan nilai konstanta pegas. Tahap terakhir adalah menarik kesimpulan analisis data.

Rancangan percobaan dalam penelitian disajikan pada Gambar 8 dibawah ini,

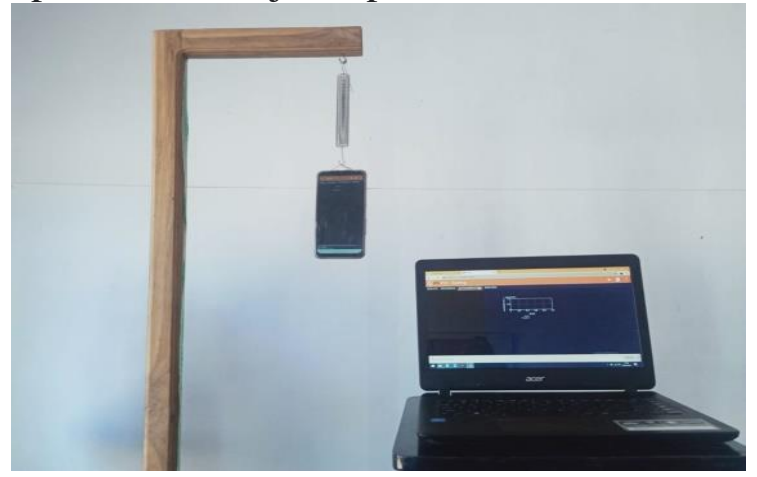

Gambar 8. Rancangan Percobaan

\section{HASIL DAN PEMBAHASAN}

1. Hasil Percobaan 1

Data hasil percobaan 1 dengan massa Smartphone 180 gram dan massa pegas 10 gram. Penambahan massa untuk setiap percobaan pada pegas 1 sebesar 10 gram. Data percobaan 1 ditampilkan dalam Tabel 1 berikut.

Tabel 1. Percobaan Pegas 1

\begin{tabular}{crrrrrr}
\hline No & $\mathbf{m}(\mathbf{k g})$ & \multicolumn{1}{c}{$\boldsymbol{l}_{\mathbf{0}}(\boldsymbol{m})$} & \multicolumn{1}{c}{$\boldsymbol{l}_{\mathbf{1}}(\boldsymbol{m})$} & \multicolumn{1}{c}{$\mathbf{T}(\mathbf{s})$} & $\mathbf{f}(\mathbf{H z})$ & $\mathbf{k}(\mathbf{N} / \mathbf{m})$ \\
\hline 1 & 0.19 & 0.06 & 0.29 & 1.06 & 0.94 & 6,669 \\
2 & 0.24 & 0.06 & 0.36 & 1.19 & 0.84 & 6,684 \\
3 & 0.29 & 0.06 & 0.445 & 1.31 & 0.76 & 6,665 \\
4 & 0.34 & 0.06 & 0.50 & 1.41 & 0.71 & 6,745 \\
5 & 0.39 & 0.06 & 0.575 & 1.5 & 0.66 & 6,836 \\
6 & 0.44 & 0.06 & 0.655 & 1.6 & 0.63 & 6,778 \\
7 & 0.49 & 0.06 & 0.72 & 1.67 & 0.6 & 6,929 \\
8 & 0.54 & 0.06 & 0.815 & 1.75 & 0.57 & 6,954 \\
9 & 0.59 & 0.06 & 0.91 & 1.81 & 0.55 & 7,103 \\
10 & 0.64 & 0.06 & 1.01 & 1.87 & 0.53 & 7,218 \\
\hline
\end{tabular}

Berdasarkan Tabel 1 hubungan antara massa $(\mathrm{m})$ dan kuadrat periode $\left(\mathrm{T}^{2}\right)$ dapat diperoleh melalui persamaan regresi linear. Hubungan antara massa dan kuadrat periode, serta persamaan regresi percobas pegas 1 tampak dalam Gambar (8) berikut: 


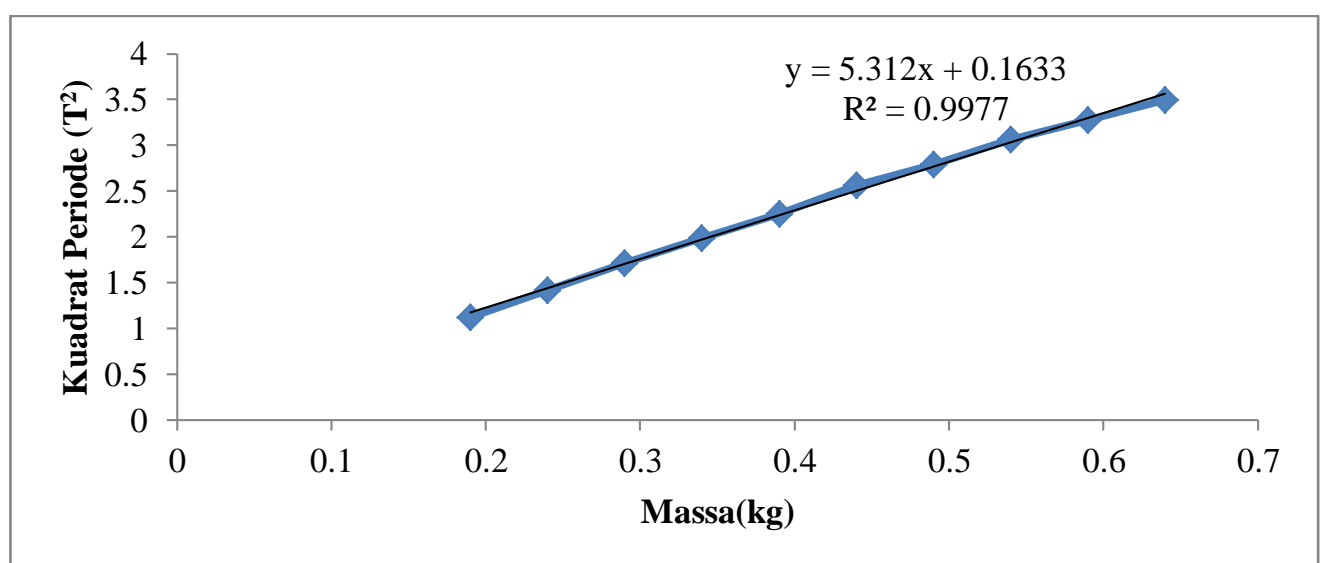

Gambar 9. Grafik hubungan antara massa dengan periode pegas 1

Dari Gambar 9, persamaan regresi $y=5,312 x+0,1633$ maka maka gradiennya adalah 5,312. Dengan meninjau Pers. (5), $\frac{4 \pi^{2}}{k}=5,312$, dengan demikian $\mathrm{k}=7,424 \mathrm{~N} / \mathrm{m} \pm 0,00092$

Pada percobaan 1 , pegas dengan massa awal $0,19 \mathrm{~kg}$ diberi simpangan $\pm 5 \mathrm{~cm}$ menghasilkan periode $1,06 \mathrm{~s}$ dan frekuensi $0,94 \mathrm{~Hz}$ kemudian percobaan diulang selama $10 \mathrm{kali}$ dengan menambah beban bermassa $0,05 \mathrm{~kg}$.dapat dilihat Pada Tabel 1 di atas bahwa setiap kali pertambahan massa, periodenya semakin besar dan frekunsi semakin kecil.

2. Hasil Percobaan 2

Data hasil percobaan 2 dengan massa Smartphone 180 gram dan massa pegas 50 gram. Penambahan massa untuk setiap percobaan pada pegas 2 sebesar 50 gram. Data percobaan 2 ditampilkan dalam Tabel 2 berikut.

Tabel 2.Percobaan Pegas 2

\begin{tabular}{ccccccc}
\hline No & $\mathbf{m}(\mathbf{k g})$ & $\boldsymbol{l}_{\mathbf{0}}(\boldsymbol{m})$ & $\boldsymbol{l}_{\mathbf{1}}(\boldsymbol{m})$ & $\mathbf{T}(\mathbf{s})$ & $\mathbf{f}(\mathbf{H z})$ & $\mathbf{k}(\mathbf{N} / \mathbf{m})$ \\
\hline 1 & 0.230 & 0.15 & 0.35 & 0.90 & 1.11 & 11,20 \\
2 & 0.280 & 0.15 & 0.38 & 1.00 & 1.00 & 11,04 \\
3 & 0.330 & 0.15 & 0.44 & 1.09 & 0.92 & 10,95 \\
4 & 0.380 & 0.15 & 0.49 & 1.17 & 0.86 & 10,95 \\
5 & 0.430 & 0.15 & 0.55 & 1.24 & 0.81 & 11,03 \\
6 & 0.480 & 0.15 & 0.58 & 1.32 & 0.76 & 10,86 \\
7 & 0.530 & 0.15 & 0.62 & 1.38 & 0.73 & 10,98 \\
8 & 0.580 & 0.15 & 0.68 & 1.44 & 0.69 & 11,03 \\
9 & 0.630 & 0.15 & 0.70 & 1.50 & 0.66 & 11,04 \\
10 & 0.680 & 0.15 & 0.77 & 1.56 & 0.64 & 11,02 \\
\hline
\end{tabular}

Berdasarkan Tabel 2, hubungan antara massa $(\mathrm{m})$ dan kuadrat periode $\left(\mathrm{T}^{2}\right)$ dapat diperoleh melalui persamaan regresi linear. Hubungan antara massa dan kuadrat periode, serta persamaan regresi percobas pegas 2 tampak dalam Gambar 10 berikut:

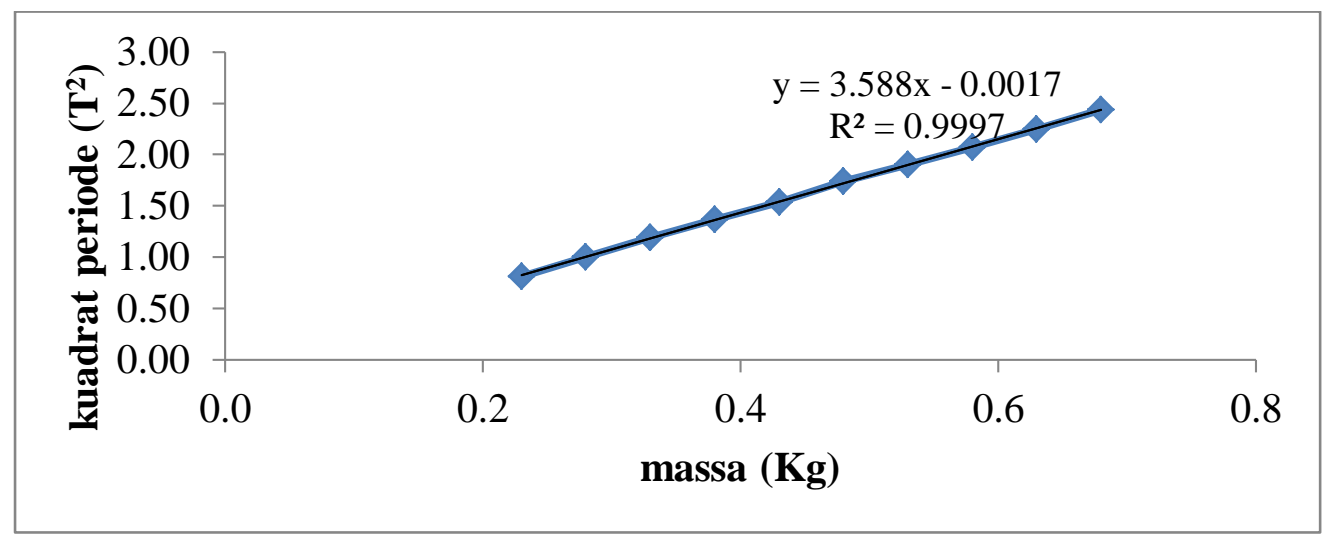

Gambar 10. Grafik hubungan antara massa dengan periode pegas 2 
Dari Gambar 10, persamaan regresi $y=3,588 x-0,0017$ maka maka gradiennya adalah 3,588. Dengan meninjau persamaan $(5), \frac{4 \pi^{2}}{k}=3,588$, dengan demikian $\mathrm{k}=11,084 \mathrm{~N} / \mathrm{m} \pm 0,00078$.

3. Hasil Percobaan 3

Data hasil percobaan 3 dengan massa Smartphone 180 gram dan massa pegas 50 gram. Penambahan massa untuk setiap percobaan pada pegas 3 sebesar 100 gram. Data percobaan 3 ditampilkan dalam Tabel 3 berikut:

Tabel 3. Percobaan Pegas 3

\begin{tabular}{ccccccc}
\hline No & $\mathbf{m}(\mathbf{k g})$ & $\boldsymbol{l}_{\mathbf{0}}(\boldsymbol{m})$ & $\boldsymbol{l}_{\mathbf{1}}(\boldsymbol{m})$ & $\mathbf{T}(\mathbf{s})$ & $\mathbf{f}(\mathbf{H z})$ & $\mathbf{k}(\mathbf{N} / \mathbf{m})$ \\
\hline 1 & 0.23 & 0.13 & 0.22 & 0.6 & 1.65 & 25,20 \\
2 & 0.33 & 0.13 & 0.26 & 0.73 & 1.37 & 24,42 \\
3 & 0.43 & 0.13 & 0.29 & 0.83 & 1.2 & 24,62 \\
4 & 0.53 & 0.13 & 0.32 & 0.93 & 1.08 & 24,17 \\
5 & 0.63 & 0.13 & 0.37 & 1.02 & 0.98 & 23,88 \\
6 & 0.73 & 0.13 & 0.41 & 1.08 & 0.93 & 24,68 \\
7 & 0.83 & 0.13 & 0.45 & 1.16 & 0.86 & 24,33 \\
8 & 0.93 & 0.13 & 0.49 & 1.21 & 0.82 & 25,05 \\
9 & 1.03 & 0.13 & 0.53 & 1.28 & 0.78 & 24,79 \\
10 & 1.13 & 0.13 & 0.58 & 1.34 & 0.75 & 24,82 \\
\hline
\end{tabular}

Berdasarkan Tabel 3, hubungan antara massa (m) dan kuadrat periode $\left(\mathrm{T}^{2}\right)$ dapat diperoleh melalui persamaan regresi linear. Hubungan antara massa dan kuadrat periode, serta persamaan regresi percobas pegas 3 tampak dalam Gambar 11 berikut:

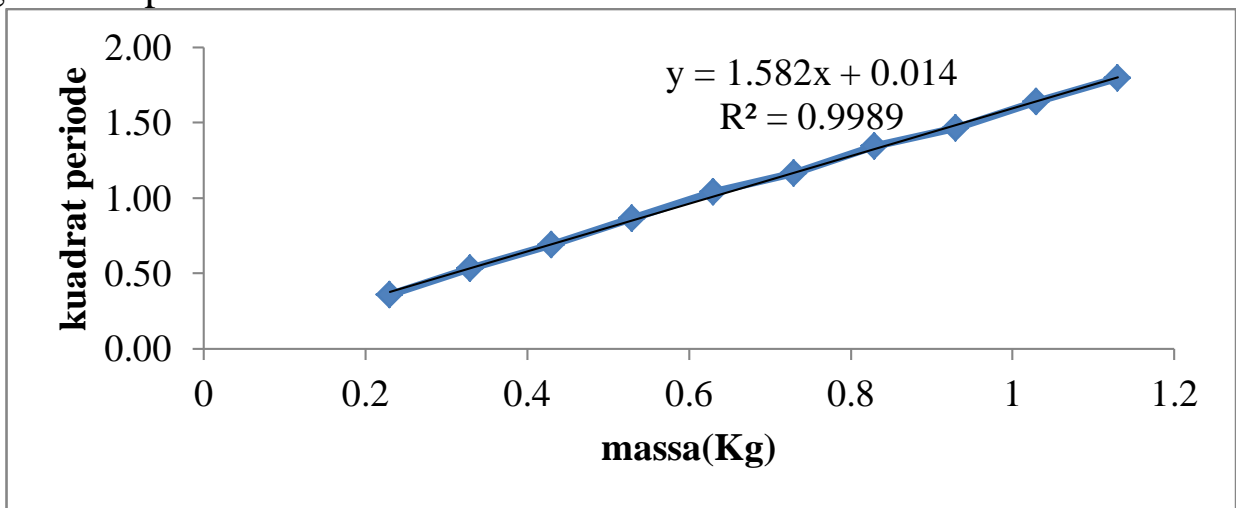

Gambar 11. Grafik hubungan antara massa dengan periode pegas 3

Dari Gambar 11, persamaan regresi $y=1,582 x+0.014$ maka maka gradiennya adalah 1,582. Dengan meninjau persamaan (5), $\frac{4 \pi^{2}}{k}=24,92$, dengan demikian $\mathrm{k} 24,92 \mathrm{~N} / \mathrm{m} \pm 0,0016$.

Pada percobaan 3 pegas dengan massa awal 0,23 kg diberi simpangan $\pm 5 \mathrm{~cm}$ menghasilkan periode $0,6 \mathrm{~s}$ dan frekuensi $1,65 \mathrm{~Hz}$ kemudian percobaan diulang selama $10 \mathrm{kali}$ dengan meambah beban bermassa $0,1 \mathrm{~kg}$.dapat dilihat Pada table diatas bahwa setiap kali pertambahan massa periodenya semakin besar dan frekunsi semakin kecil.

\section{SIMPULAN DAN SARAN}

\subsection{Simpulan}

Hasil penelitian menggunakan menu spring pada aplikasi phyphox menunjukkan: 1) pegas 1 dengan massa $10 \mathrm{~g}$ dan panjang $6 \mathrm{~cm}$ memiliki konstanta sebesar 7,424 N/m $\pm 0,00092,2$ ) pegas 2 dengan massa $50 \mathrm{~g}$ dan panjang $15 \mathrm{~cm}$ memiliki konstanta sebesar 11,084 N/m $\pm 0,00078$, dan 3) pegas 1 dengan massa $50 \mathrm{~g}$ dan panjang $\mathrm{cm}$ cm memiliki konstanta sebesar 24,92 N/m \pm 0,0016. 4.2 Saran

Perlu penelitian lanjutan untuk membandingkan nilai konstanta pegas saat sistem pegas diam dan sistem pegas berosilasi agar mengetahui perbedaan nilai konstantanya. 


\section{DAFTAR PUSTAKA}

1. Rahmatullah S, Arman Y, Apriansyah A. Simulasi Gerak Osilasi Model Pegas Bergandeng Menggunakan Metode Runge-Kutta. Prism Fis. 2020;8(Desember):180-4.

2. Nurullaeli IADA. Media Analisis Osilator Harmonik Pada Pegas Berbasis Graphic User Interface (GUI). J Pendidik Fis. 2019;(Mei):245-55.

3. Vivi Eka Oktavia, Miftachul Khoiriah PAR. Tetapan Pegas. J Fis dasar. 2015;(Desember):17.

4. Walker J, Halliday D, Resnick R. Fundamentals of Physics. 10th ed. Wiley. USA: Wiley; 2007. 1-1450 p.

5. Khoirina M, Cari C, Sukarmin. ANALYSIS OF SPRING'S CONSTANTANT VALUE BY COMBINING THE CONCEPTS OF HOOKE'S LAW AND ARCHIMEDES' LAW. J Ilmu Pendidik Fis. 2018;3(2):55-8.

6. Tong-on A, Saphet P, Thepnurat M. Simple Harmonics Motion experiment based on LabVIEW interface for Arduino.

7. Erol M, Kaya Ş, Hocaoğlu K. Measurement of spring constants of various spring-mass systems by using Smartphones : A teaching proposal. Momentum Phys Educ J. 2020;4(1):110 .

8. Kuhn J, Vogt P. Applications and Examples of Experiments with Mobile Phones and Smartphones in Physics Lessons. Front Sensors. 2013;1(4).

9. Kaps A, Splith T, Stallmach F. Implementation of Smartphone-based experimental exercises for physics courses at universities. Phys Educ. 2021;56.

10. Nuryantini AY, Yudhiantara RA. The Use of Mobile Application as a Media in Physics Learning. J Penelit dan Pembelajaran IPA. 2019;5(1):72.

11. S Staacks , S Hütz HH and CS. Advanced tools for Smartphone- based experiments : phyphox. Phys Educ. 2018;

12. Shelin Novitasari, Djeli Alvi Tulandi JL. Pengembangan Panduan Praktikum Online Menggunakan Smartphone Berbasis Aplikasi Phypox. J Pendidik Fis. 2021;2(Februari):3542.

13. Dea Julianingsih, S Supryatna NA. Kefektivitasan Aplikasi phyphox dan Pratikum Sederhana Pegas Sebagai Media percobaan Dalam Menentukan Nilai Konstanta Pegas pada Teknologi Pembejaran Fisika. physEductech. 2019;(juli):1.

14. Colt M, Sebe C. Smartphone used in physics experiments. Int Conf Virtual Learn ICVL. 2019;524-30. 